\title{
THE EUROPEAN UNIONS HEALTH AND SAFETY POLICY: ANALYSIS OF RISK ASSESSMENT AND MANAGEMENT
}

\author{
Algis Junevicius \\ Kaunas University of Technology, Institute of Europe
}

\begin{abstract}
Safety and health at work comprises all preventative measures aimed at protecting functional capacity, health and life of employees at work which are used or planned at all operational stages of the company to protect employees from occupational risks or minimise these risks. The main objective of occupational safety and health is to maintain and develop health, safety and work ability of the employee, as well as to prevent occupational accidents and illnesses. In a democratic country every human has got an inborn and constitutional right to free choice of work and business, as well as to have favourable, safe and healthy working conditions. Every employee must be provided with secure and healthy working environment irrespective of the activities of the company, type of employment contract, number of employees, profitability of the company, work place, working environment, nature of work, duration of the working day or shift, citizenship, race, nationality, gender, sexual orientation, age, social background, political or religious beliefs of the employee. Employers have a general duty to ensure the safety and health of workers in every aspect related to work. The main role of the European Union in health and safety is to harmonize workplace and legal standards and remove barriers to trade across member states. The directives of the EU set out minimum requirements and fundamental principles, such as the principle of prevention and risk assessment, as well as the responsibilities of employers and employees. The Framework Directive with its wide scope of application as well as further directives focusing on specific aspects of safety and health at work are the fundamentals of European safety and health legislation. European directives are legally binding and have to be transposed into national laws by the Member States. The current EU Strategy for the period 2007-2012 is focussing on prevention. In the Commission's view, the overall objective during this period should be to reduce by $\mathbf{2 5 \%}$ the total incidence rate of accidents at work. To achieve this objective it calls for action by players at all levels - European, national, local and workplaces. National and EU policies should help to create working environments and occupational health services which enable workers to play a full and protective part in working life until they reach old age.

This article reveals an empoyer responsibility to guarantee safe and healthy working conditions for employees, in accordance with EU legislation and policy. Equally, this article highlights the importance of risk assessment. Risk assessment is the cornerstone of the European approach to occupational safety and health. It is the key to preventing accidents and illness at work and occupational risks must be assessed in every company. Risk assessment enables employers to understand the action that they need to take, to eliminate or minimise the risks to their employees. If the risk assessment process is not done well or not done at all, the necessary preventive measures are unlikely to be identified or put in place. It must be remembered that risk assessment is the start of the process of safety and health management. Good health and safety is good business, and proper risk assessment is worth investing in.
\end{abstract}

Keywords: European Union, health and safety at work, risk assessment.

\section{Introduction}

Creation of the safe and healthy operating conditions is an inseparable part of a full - value work: if the job is well paid but not safe, it cannot be considered as a full - value work. Employers have responsibilities for the health and safety of their employees. All employers, whatever the size of the business, must follow safety and healthy ensuring regulations, prevent risks to health and make the workplace safe. Workers have responsibilities as well. The worker shall make correct use of machinery, apparatus, tools, dangerous substances, transport equipment, other means of production and personal protective equipment and similarly cooperate with the employer in fulfilling any requirements imposed for the protection of health and safety and in enabling him to ensure that the working environment and working conditions are safe and pose no risks. Workplace health promotion means more than simply meeting the legal requirements on health and safety; it also means employers actively helping their staff improve their own general health and wellbeing.
Within this process it's essential to involve employees and to take into account their needs and views on how to organise work and the workplace. Despite the fact that, more and more employers have an interest in keeping workers safe and healthy, the figures on accidents and illness at work show that improvements are needed.

Problem. The problem of health and safety at work is particularly topical. Every year in the European Union there are plenty of fatal work-related accidents and millions of people are injured or have their health seriously harmed in the workplace. Health and safety at work is now one of the most important and most highly developed aspects of EU policy on employment and social affairs. The current Commission's target to reduce $25 \%$ of work accidents across the EU requires guarantee the proper implementation of EU legislation. Another topical problem is risk assessment. Risk assessment is still a gap at workplace level. In spite of the fact that the EU Framework Directive on occupational safety and health requires risk assessment to be carried out in all companies and some companies are doing excellent work, it is not universally 
done. Occupational risks must be assessed in every company. It is essential to provide employers and employees with the guidance, information and resources that they need, to carry out proper risk assessments and keep the workplace safe.

Aim of the article is to analyse risk assessment and management in companies of occupational health and safety policy.

Object of the article - the occupational health and safety regulation;

Tasks of this article:

- to reveal main aspects of the EU occupational health and safety policy;

- to analyse occupational health and safety legislation of the EU;

- to identify common principles of risk assessment and management in companies.

Research methods: analysis of primary and secondary literature.

\section{Occupational health and safety policy in the European Union}

Create more jobs and of better quality: this is one of the main objectives of the EU social policy. A safe and healthy working environment is an essential element of the quality of work. There is no doubt that health and safety at work represents today one of the most important advanced fields of the social policy of the European Union (The European Commission). Action of the EU is not limited to legislation. Occupational health and safety policy is not only a matter of laws and regulations - they are essential and have to be applied at the workplace level. To achieve measurable improvements of the working conditions and a reduction of occupational accidents and diseases it is necessary to combine them with a variety of other instruments, such as social dialogue, good practices, awareness raising, corporate social responsibility, economic incentives and mainstreaming. Work in this field is a complex interaction between various actors at EU and Member State level, including in particular governments and other public authorities, as well as workers' and employers' organisations. At EU-level, this holistic approach towards OSH has been adopted in the form of Community strategies on health and safety at work. (European Agency for Safety and Health at Work).

On 21 February 2007, the European Commission published a communication setting out its proposals for a new European occupational safety and health strategy to run from 2007-2012. The new strategy is called „Improving quality and productivity at work $^{[1]}$ : Community strategy 2007-2012 on health and safety at work". This strategy succeeds the former strategy ,Adapting to change in work and society: a new Community strategy on health and safety at work 20022006 ". The EU Strategy for the period 2002-2006 adopted a global approach to well-being in the workplace. It emphasised the culture of risk prevention, the combination of a variety of political instruments and the building of partnerships between all the players on the safety and health scene. It pointed at the fact that an ambitious social policy is a factor in the competitiveness equation and that, conversely, having a 'nonpolicy' engenders costs which weigh heavily on economies and societies (European Parliament). Over the period 20002006, the rate of fatal accidents at work in the EU has fallen by
$17 \%$ while the rate of workplace accidents leading to absences of more than three days has fallen by $20 \%$ (Improving quality and productivity at work: Community strategy 2007-2012 on health and safety at work).

The current EU Strategy for the period 2007-2012 is focussing on prevention. It aims to achieve a continuous, sustainable and homogeneous reduction of occupational accidents and diseases in the EU, in particular through defining and implementing national strategies based on a detailed evaluation of the national situation and improving and simplifying existing legislation as well as enhancing its implementation in practice through non-binding instruments such as exchange of good practices, awareness-raising campaigns as well as better information and training (The European Parliament). The current Commission's target to reduce $25 \%$ of work accidents across the EU is very ambitious. In order to achieve this ambitious target, the following main instruments are proposed:

- guarantee the proper implementation of EU legislation;

- support SME's in the implementation of the legislation in force;

- adapt the legal framework to changes in the workplace and simplify it, particularly in view of SME's;

- promote the development and implementation of national strategies;

- encourage changes in the behaviour of workers and encourage their employers to adopt health-focused approaches;

- finalise the methods for identifying and evaluating new potential risks;

- improve the tracking of progress;

- promote health and safety at international level.

It is generally agreed that the lack of effective protection to ensure health and safety at work can result in absenteeism, in the wake of workplace accidents and occupational illnesses, and can lead to permanent occupational disability. This not only has a considerable human dimension but also has a major negative impact on the economy. The enormous economic costs of problems associated with health and safety at work inhibits economic growth and affects the competitiveness of businesses in the EU. A considerable share of these costs also falls upon social security systems and public finances (Improving quality and productivity at work: Community strategy 2007-2012 on health and safety at work). Health is central in people's lives and needs to be supported by effective policies and actions in Member States, and at EU level as well. The base of the EU Strategic Approach on Safety and Health includes European Directives, Strategies and European Agency for Safety and Health at work ( see Figure 1).

There are many actors involved in occupational safety and health across Europe. In addition to the EU and the competent OSH authorities in the Member States, the social partners, various OSH networks and professional organisations as well as international organisations such as ILO and WHO play a role and contribute to achieving modern, effective and efficient occupational health and safety for Europe. An important role of the European Agency for safety and health at work estimate information available to support and promote the prevention of risk to workers, helping employers and others with legal duties to comply with national legislation based on the directives and helping to include risk awareness education within their activities (Tartilas, 2008). 


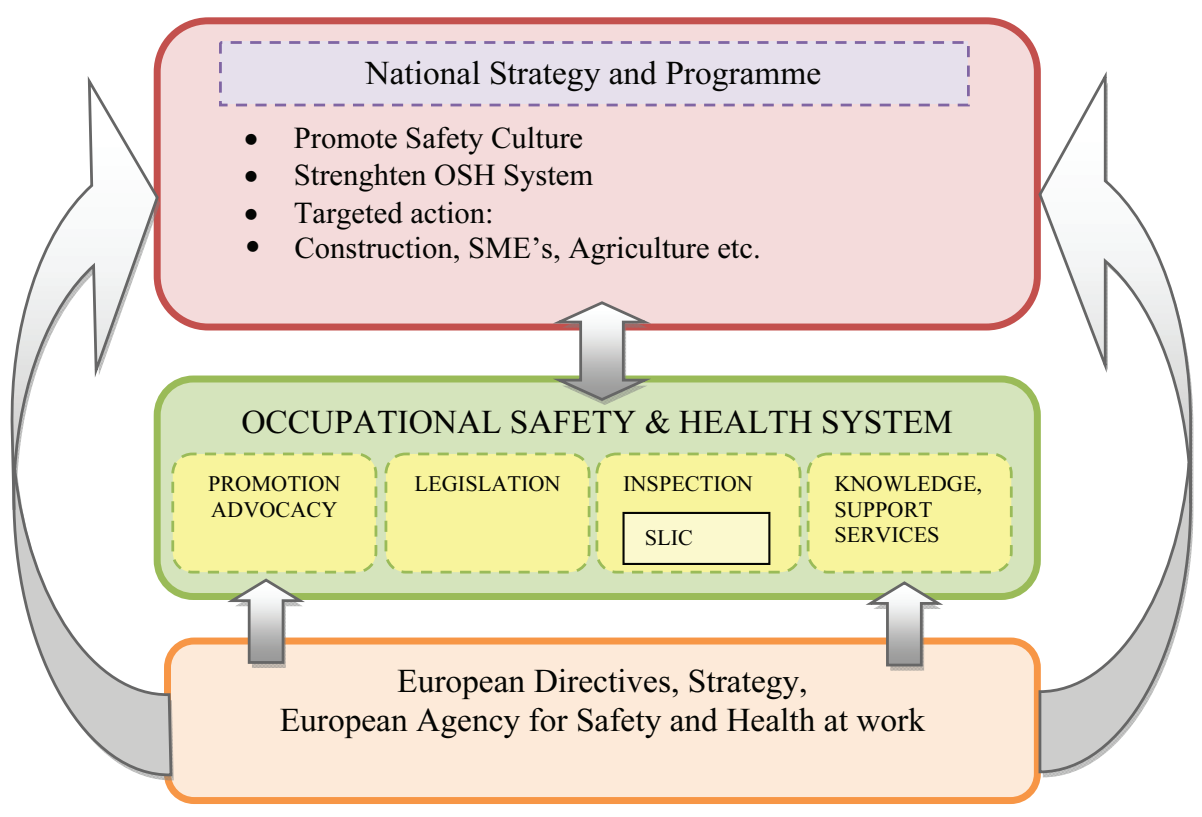

Figure 1. EU Strategic Approach on Safety and Health (Takala, 2010)

The European Agency for safety and health was set up by the European Union in order to meet the increasing needs for information in the field of safety and health at work. Contributing to safer, healthier and more productive workplaces is EU-OSHA's vision this year and this vision is perfectly in line with the "Europe 2020" strategy which says "Europe needs to make full use of its labour potential to face the challenges of an ageing population and rising global competition". Going from the current 69 percent of the population aged 20-64 in employment to 75 percent in 2020 is not going to be achieved without a considerable contribution from better occupational safety and health at European workplaces. EU-OSHA fully recognises its responsibility and role in contributing to the aim of creating smart, sustainable and inclusive economy with high levels of employment, productivity and social cohesion. Better working conditions is one of the key contributions to reducing health inequalities and promoting a healthy and active ageing population. (2011 Annual Management Plan \& Work Programme of EU-OSHA).

\section{Occupational health and safety legislation in the European Union}

The Charter of Fundamental Rights, which became legally-binding with the Lisbon Treaty, only reinforces the importance of occupational health and safety policy in the European legislation. The main role of the EU in health and safety is to harmonize workplace and legal standards and remove barriers to trade across member states. The EU action in health and safety at work has its legal basis in Article 153 of the Treaty on the Functioning of the European Union (ex Article 137 ot the EC Treaty). On the basis of this Article the EU encourages improvements in the working environments in order to protect workers' health and safety by harmonising working conditions. To this end, minimum requirements are laid down at the EU level (The European Parliament).

The EU's work in the area of the prevention and protection of the health and safety of workers at work began as far back as 1952 under the European Coal and Steel Community. In line with the Treaty, the EU defines at European level the minimum requirements in the field of health and safety at work. In other words since 1952 a solid corpus of legislation has been adopted covering the maximum number of risks with the minimum number of regulations (European Commission). The first European directives on safety and health at work were adopted on the basis of the general market harmonisation provisions (ex Articles 100 and 100a TEC). This was due to a lack of an explicit legislative competence in the Treaty in the field of safety and health at work until the mid-1980s. Until then occupational safety and health was seen as an annex to market harmonisation and the economic policies of the European Economic Community. The Single European Act 1987 was a major step forward in that it introduced a new legal provision on social policy to the Treaty aiming at 'improvements, especially in the working environment, as regards the health and safety of workers'. With the Treaty of Amsterdam in 1997, the legislative competence in the fields of European social policies was further strengthened by the incorporation of the social agreement into the EC Treaty. The Lisbon Treaty - apart from the renumbering of the Articles on social policy - kept the substance of the provisions of ex Articles $136 \mathrm{ff}$ TEC (now Articles $151 \mathrm{ff}$ of the Treaty on the Functioning of the European Union) (European Agency for Safety and Health at Work).

A directive from the EU is legally binding on each member state and must be incorporated into the national law of each member state. Directives set out specific minimum aims which must be covered within the national law. One of the cornerstones in the development of the safety and health of work was the adoption of the Framework Directive 89/391/ EEC. The object of the measures introduced by Council Directive $89 / 391 /$ EEC is to encourage improvements in the safety and health of workers at work. It contains general principles concerning the prevention of occupational risks, the protection of safety and health, the elimination of risk and accident factors, the informing, consultation, balanced participation and training of workers and their representatives as well as general guidelines for the implementation of these 
principles. Member States must ensure that the provisions of the directive are applied to employers, workers and workers' representatives. In particular, there must be adequate controls and supervision. The directive applies to all sectors of activity, both public and private (industrial, agricultural, commercial, administrative, service, educational, cultural, leisure, etc.) However, it is not applicable where characteristics peculiar to certain specific public service activities in the civil protection services inevitably conflict with it. In that event, the safety and health of workers must be ensured as far as possible in the light of the objectives of the directive (Quigley, 2003).

Under the umbrella of the 1989 "Framework" Directive, a number of so-called "daughter directives" have also been adopted, all of which incorporate the general provisions of the framework, and all of which refer, specifically, to the dramatically extended "social dialogue" provisions. In particular "daughter directives" have been adopted on the minimum safety and health requirements for the workplace, on the minimum safety and health requirements for the use of work equipment by workers at work, on the minimum health and safety requirements for the use by workers at work, on the minimum health and safety requirements for the use by workers of personal protective equipment at the workplace, on the minimum health and safety requirements for the manual handling of loads where there is a risk particularly of back injury to workers, and on the minimum safety and health requirement for work with visual screen equipment (Neal, Wright 1992). The Framework Directive is the basis for in total 19 "daughter directives" (see Figure 2).

The Framework Directive have had an impact on other legislative acts, in particular on the Commission's proposal to amend the Directive 91/383/EEC on temporary agency workers; the proposal to amend Directive 2003/88/EC on certain aspects of the organisation of working time; on Directive 99/95/EC on working time provisions in maritime transport; on Directive 2000/34/EC concerning certain aspects of the organisation of working time to cover sectors and activities excluded from that directive (road, air, sea and rail transport, inland waterways, sea fishing, other work at sea and the activities of doctors in training); on Directive 94/33/EC on the protection of young people at work; and on the Council Regulation (EC) No 2062/94/EEC established the European Agency for Health and Safety at Work (The European Parliament).

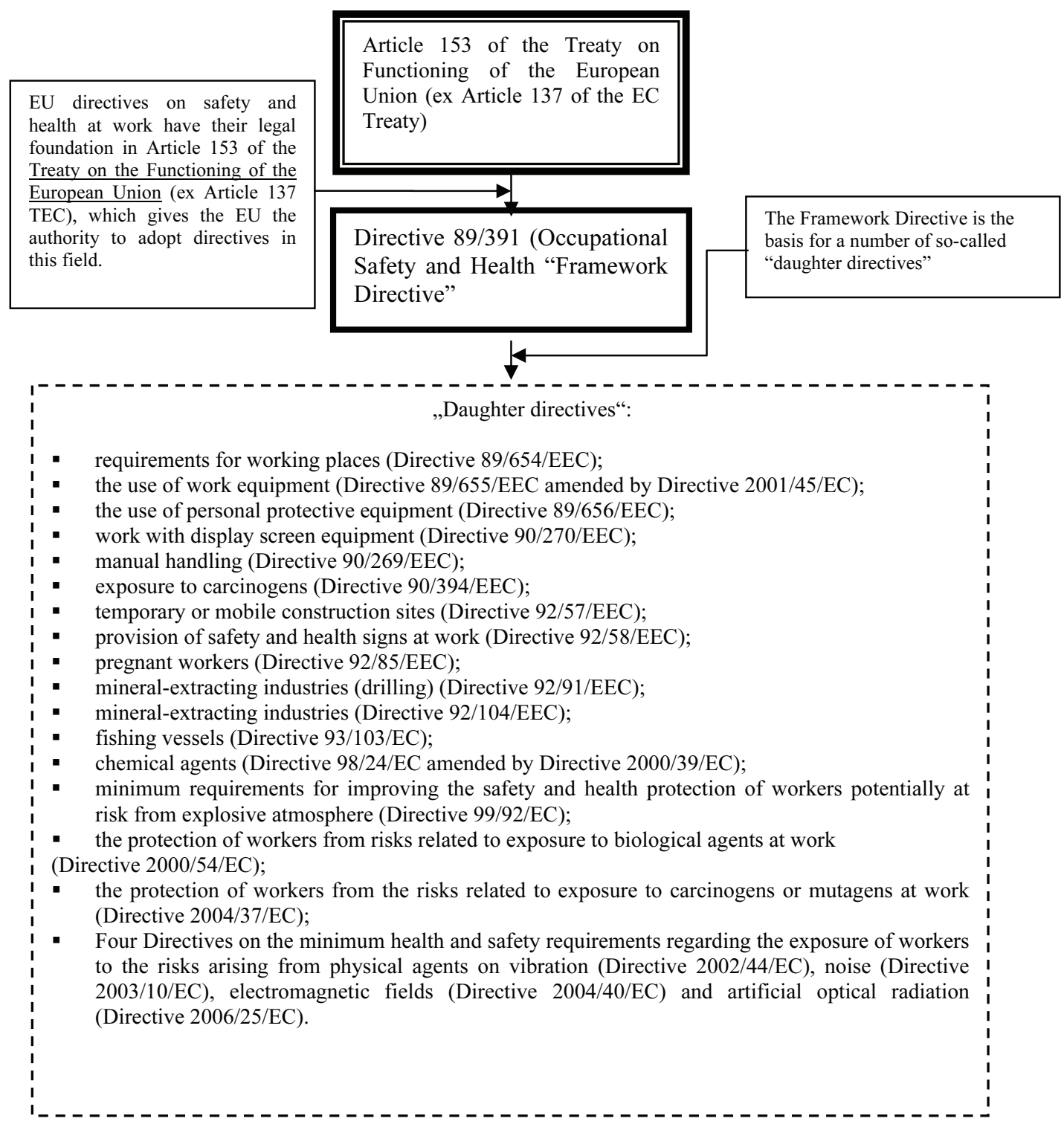

Figure 2. Scheme of European safety and health legislation 
The Framework Directive with its wide scope of application as well as further directives focusing on specific aspects of safety and health at work are the fundamentals of European safety and health legislation. These directives set out minimum requirements and fundamental principles, such as the principle of prevention and risk assessment, as well as the responsibilities of employers and employees. EU directives on safety and health at work have their legal foundation in Article 153 of the Treaty on the Functioning of the European Union (ex Article 137 TEC), which gives the EU the authority to adopt directives in this field. European directives are legally binding and have to be transposed into national laws by the Member States. It should be noted that Member States are free to adopt stricter rules for the protection of workers when transposing EU directives into national law, and so legislative requirements in the field of safety and health at work can vary across EU Member States. In Lithuania, safety and health at work is regulated by Labour Code, Law on Safety and Health at Work, other laws, and legislation adopted by Government regulations and orders of the ministres (Lietuvos Respublikos Socialinès apsaugos ir darbo ministerija).

\section{Risk assessment and management in companies}

Risk assessments are at the core of the European approach to a preventive occupational safety and health culture as they are the key tools at the workplace level to identify and initiate actions to prevent risks. Though the importance of risk assessment is recognized and though risk assessment is a key concept in the Framework Directive on occupational safety and health the implementation of risk assessment at the workplace level is still far from satisfactory. Every three-and-a-half minutes, someone in the EU dies from work-related causes. This adds up to around 167,000 deaths a year from workrelated accidents and occupational disease. Every four-and-ahalf seconds, a worker in the EU is involved in an accident that forces them to stay at home for at least three working days. That adds up to over 7 million every year. Data and statistics about accidents and illnesses at work show that improvements are urgently needed (Interview with Jukka Takala, Director of the European Agency for Safety and Health at Work).

In Guidance on risk assessment at work, the European Commission defined risk assessment as "the process of evaluating the risk to the health and safety of worker while at work arising from the circumstances of the occurrence of a hazard at the workplace".(...) "Risk assessment is a systematic examination of all aspects of work that identifies the hazards that could cause harm, assesses whether these hazards can be eliminated and, if not, suggests preventive or protective measures to control the risks". It must be remembered that a hazard is the potential of a substance, activity or process to cause harm. Hazards take many forms including, for example, chemicals, electricity and the use of ladder. A hazard can be ranked relative to other hazards or to a possible level of danger (Hughes, Ferret, 2009).

The key role played by risk assessment is set out in the Directive 89/391. This Occupational health and safety "Framework Directive" guarantees minimum safety and health requirements throughout Europe while Member States are allowed to maintain or establish more stringent measures. Risk assessment is a requirement under European legislation enacted in all Member States. Risk assessment means identifying what may cause harm so that preventive measures can be taken. Proper risk assessment is the basis for successful risk management. Training workers on the basis of risk assessment for safe work practices is an important part of risk management. Trained workers can not only apply the rules but also work more efficiently and promote a healthy and safe working environment (An introduction to dangerous substances in the workplace). In order to carry out effective workplace risk assessment, all those involved require a clear understanding of the legal context, definitions, the purpose of risk assessment, the process of assessing the risks and the role to be played by the main actors involved in the process.

In occupational health and safety terms, the purpose of risk assessment is to enable a valid decision to be made about measures necessary to control exposure to substances hazardous to health arising in any workplace. It enables the employers to demonstrate that all factors pertinent to the work have been considered, and that a valid judgement has been reached about the risks. An important part of the assessment process is to define clearly the stages which need to be taken to achieve and maintain adequate control. (Sahra, Rampal, 1999). There are three stages of the risk assessment process: planning the risk assessment stage, carrying out the risk assessment stage and documenting the risk assessment stage (see Figure 3).
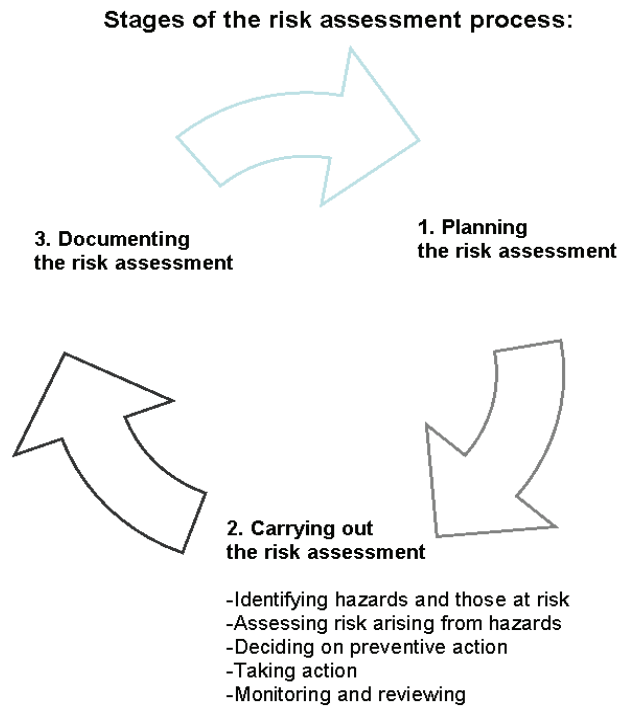

Figure 3. Stages of the risk assessment process (European Agency for Safety and Health at work)

Employers should carefully prepare a risk assessment and take all measures necessary to ensure the safety and health protection of workers. The preparation stage includes: commissioning, organising and coordinating the assessment appointing competent people to make the assessment consulting workers' representatives on the arrangements for appointing the people who will carry out the assessments providing the necessary information, training, resources, time and support to assessors who are employed by the organisation. Risk assessment can be a challenge, especially for small businesses. But it need not be so. Risk assessment is not necessarily complicated, bureaucratic, or a task only for experts. A simple, step-by-step approach is often all that is needed, and many resources and examples of good practice are available, to help make the process easier. The guiding principles that should be considered throughout the second stage of the risk assessment process can be broken down into five steps (see Figure 4). 


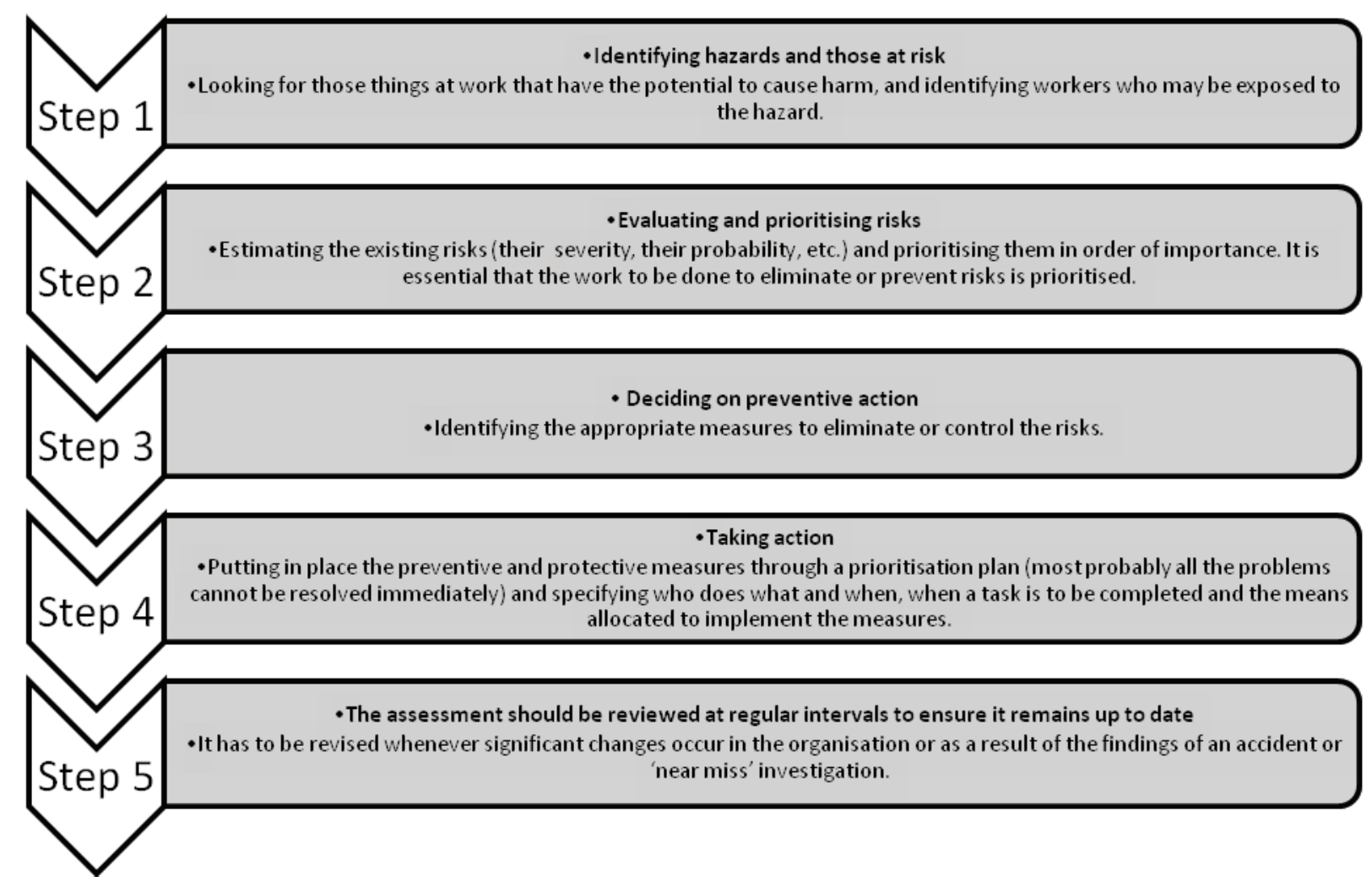

\section{Figure 4. Five steps of the second stage of the risk assessment process}

The last stage of the risk assessment process is the documenting stage. Article 9 of the Framework Directive states that the employer shall be in possession of an assessment of the risks to safety and health at work, including those facing groups of workers exposed to particular risks. A risk assessment sheet with several appendices is a suitable form for documenting the results of a risk assessment. A general form can exist providing an overview of hazards, risks and subsequent measures, with extra forms for each department in the enterprise (E-Facts 32 - Common errors in the risk assessment process).

The actual risk assessment process is very different in different companies. Businesses have different organisational structures, needs, risks, and resources, so the same methods do not suit everyone. The best results are attained when the risk assessment is properly planned and the company's own needs are taken into account in the planning. Risk assessment methods are usually developed to suit as many companies as possible. To get the best possible results the chosen method should be adapted to suit the business's own purposes (A European Campaign on risk Assessment).

By law employers are responsible for risk assessment. But ultimately, risk assessment concerns everyone in the workplace, not just employers and experts. Everyone has a valuable contribution to make, and everyone has an interest in preventing accidents and ill health. The best risk assessments are based on partnership between employers and employees, with workers being closely involved and consulted throughout the process. It must be remembered that Risk assessment isn't just an obligation or burden. Not only does risk assessment protect workers, but there are economic benefits too. Accidents and illness at work are costly for organisations and governments. When things go wrong at work, it affects business productivity, and places a burden on healthcare systems. The creation of safe working conditions enables companies to cut costs arising from occupational accidents and illness. Proper risk assessment helps to reduce rates of sick leave, and insurance costs come down with fewer claims. More highly motivated workers are more productive and efficient, and staff turnover rates fall. This all helps businesses become more competitive (Interview with Jukka Takala, Director of the European Agency for Safety and Health at Work).

\section{Conclusions}

Health and safety at work represents today one of the most important advanced fields of the social policy of the European Union. Improvement of health and safety at work is important not only in human terms, to reduce workers' pain and suffering, but also as a way of ensuring that enterprises are successful and sustainable, and that economies thrive in the long term. For occupational safety and health improvement, the Commission introduced the Occupational Safety and Health Strategy for the period 2007-2012, which aims to promote a common approach to the wellbeing of workers, taking into account the changes in the work area, and the emergence of new risks, and reduce accidents.

The main role of the EU in health and safety is to harmonize workplace and legal standards and remove barriers to trade across member states. The key principles relating to the prevention and protection of the health and safety of workers are defined in the 1989 Framework Directive 89/391/ EEC. It constitutes the basis for all subsequent individual socalled "daughter directives". The Framework Directive with its wide scope of application as well as further directives focusing on specific aspects of safety and health at work are the fundamentals of European safety and health legislation.

The employer has a duty to ensure the safety and health 
of workers in every aspect related to work. Workers' safety and health is protected in Europe by an approach based on assessing and managing risk. In order to carry out effective workplace risk assessment, all those involved require a clear understanding of the legal context, concepts, the process of assessing the risks and the role to be played by the main actors involved in the process. Without a systematic assessment of the risks and a genuine integration of Occupational health and safety into the general management of the organisation it is not possible to develop a preventive approach - and prevention is the guiding principle for Occupational health and safety legislation in the European Union.

\section{References}

An introduction to dangerous substances in the workplace. E -Facts 33. European Agency for Safety and Health at Work. On-line: http://osha.europa.eu/en/publications/ factsheets $/ 33$

„Europe 2020“ - A European strategy for smart, sustainable and inclusive growth. The European Commission. Online: http://eunec.vlor.be/detail bestanden/doc014\%20 Europe\%202020.pdf

2011 Annual Management Plan \& Work Programme of EU-OSHA. European Agency for Safety and Health at Work. On-line: http://osha.europa.eu/en/publications/ work programmes/amp2011

Common errors in the risk assessment process. E - Facts 32. European Agency for Safety and Health at Work. Online: http://osha.europa.eu/en/publications/e-facts/efact32

Council Directive 89/391/EEC of 12 June 1989 on the introduction of measures to encourage improvements in the safety and health of workers at work. - Official Journal L 183, 29.06.1989.

European Directives. European Agency for Safety and Health at Work. On-line: http://osha.europa.eu/lt/ legislation/directives

Guidance on risk assessment at work. The European Commission.On-line: http://osha.europa.eu/en/topics/ riskassessment/guidance.pdf

Health and Safety at Work. The European Commission. On-line: http://ec.europa.eu/social/main. jsp?catId=148\&langId=en

Health and Safety at Work. The European Parliament. On-line: http://www.europarl.europa.eu/ftu/pdf/en// FTU 4.9.5.pdf
Healthy workplaces. A European Campaign on risk Assessment. On-line: http://osha.europa.eu/en/ publications/magazine/magazine11

Hughes P., Ferrett E. (2009), Introduction to Health and Safety at Work - London, Elsevier/ButterworthHeinemann, $85 \mathrm{p}$.

Improving quality and productivity at work: Community strategy 2007-2012 on health and safety at work. Communication from the Commission to the European Parliament, the Council, the European Economic and Social Committee and the Committee of the Regions. On-line: http://eur-lex.europa.eu/LexUriServ/LexUriServ. do?uri=COM:2007:0062:FIN:EN:PDF

Interview with Jukka Takala, Director of the European Agency for Safety and Health at Work. On-line: http:// osha.europa.eu/en/press/articles/Interview_JT_RA en.pdf

Neal A.C., Wright F.B. (1992), The European Communities' Health and Safety Legislation - New York, Chapman \& Hall, $21 \mathrm{p}$.

Quigley C. (2003), European Community Contract Law London, Kluwer, 242 p.

Risk assessment - roles and responsibilities. Factsheet 80. European Agency for Safety and Health at Work On-line: http://www.hsa.ie/eng/News_and_Events/European Agency_for_Safety_and_Health_at_Work/European Safety Week/Fact Sheet no 80.pdf

Risk Assessment. The Scottish Centre for Healthy Working Lives. On-line: http://www.healthyworkinglives.com/ advice/minimising-workplace-risks/risk-assessment.aspx

Sadhra S.S., Rampal K.G. (1999), Occupational Health Risk Assessment and Management - Oxford, Blackwell Science Ltd, 4 p.

Safety and Health at Work. Lietuvos Respublikos Socialinès apsaugos ir darbo ministerija. On-line: http://www. socmin.lt/index.php?1826297904

Takala J. (2010), Workplace Safety and Health as a Strategy for Success. Singapore WSH Conference, Symposium 1: Development \& Implementation of National WSH Strategies. On-line: http://osha.europa.eu/en/press/ articles/presentation-whs-singapore-2010

Tartilas J. (2008), Darbų saugos teisiniai aktai kritiniu aspektu. Jurisprudencija. - Volume 110, Nr. 8, 13-17 p.

Treaty on the Functioning of the European Union. - Official Journal C 83, 30.3.2010

The article has been reviewed.

Received in April, 2011; accepted in June, 2011. 